\title{
The Study of Advantages Communist Youth Leagues of Universities and Colleges in Supporting Students for their Employment and Enterpreneurship
}

\author{
Hongxia CUI \\ School of law, Linyi University, Shandong Province, China, 2760005 \\ cuihongxia@lyu.edu.cn
}

\begin{abstract}
It's the fundamental policy of our party and country that promote our college students' employment. To provide service to students' employment and entrepreneurship is an important function of the Communist Youth League in Colleges and Universities. In order to play the function role of the Communist Youth League, and contribute to the service of the party's central work, we should have a actively explorement from the play of the advantages of the Communist Youth League, the role of the employment of college students, the content, methods, content and methods.
\end{abstract}

Index Terms - Communist Youth League, Employment and Entrepreneurship, Role, orientation, Characteristic, advantage

\section{Introduction}

With the increasingly severe employment situation, college students' employment and entrepreneurship has become a hot social concern. And the college students are the future of the motherland, the hope of the nation, the important social issues of the national economy and the people's livelihood, the vital interests of millions of people. Promoting college students' employment and promoting employment priority is the fundamental policy of the party and state, and it is the central work of colleges and Universities. The service of university students' employment, service overall work of the party and government, promote the sustained, healthy and stable development, promote the establishment of a harmonious society is the responsibility and obligation incumbent upon the Communist Youth League in Colleges and universities.

\section{The role of the College Youth League Service College Students' employment and Entrepreneurship.}

A. Service College Students' employment and entrepreneurship is the inevitable requirement of the Communist Youth League service party and government. Employment is the basis of people's livelihood, is the party and the government has long been a high degree of importance of important issues.

Along with the transformation of economic development mode and industrial structure upgrading, economic growth in the role of employment is significantly decreased, further exacerbated the tension of the employment situation. Especially the impact of the international financial crisis and the debt crisis in Europe and the United States, China's employment situation is more severe. According to human resources and social security department statistics, 2014 China will have 7270000 graduate students, College Students. Plus last year's not found graduates, it is expected that the number of college employment in 2014 as many as 8100000 . College students are valuable human resources in the development of the country, college students are valuable human resources in the development of the country, the solution is not good, is the waste of human resources, and it is not only related to the strategic development of China from the labor power to the human resource power, more related to the overall situation of reform and development.

B. Serving college students' employment and entrepreneurship is the basic duty and the proper meaning of the basic functions of the mission.

The basic function of the Communist Youth League is to organize the youth, to guide the youth, to serve the youth and to safeguard the legitimate rights and interests of the young people, which is the fundamental duty of the regiment. College League organizations in the Youth League and college students on the border, to continue to consolidate and expand the party's ruling Youth Foundation, to achieve the basic political functions, First of all, we should think about how to attract and unite college students, so that they can form the identity of the Communist Youth League in their hearts, so that they can better guide them in their minds. To attract and unite college students must start from the realization of their universality, with the common interests of the demands. To attract and unite college students must start from the realization of their universality, with the common interests of the demands. Seize the employment and entrepreneurship, to seize the key to attract and unite college students, found the important way to achieve the basic functions and basic functions of the College League. And this work is a long-term, strategic and global work closely related to the nature of the Communist Youth League and the principle of work.

C. The service of university students' employment is an important starting point and the goal of education of the Communist Youth League service way.

Education is the basic function of the University, the Communist Youth League service education goal, the focus is the college students' thought lead and growth service. Thought leading is to use the ideal and belief of socialism with Chinese characteristics to educate and guide the young college students, this is the party's requirements for the Communist 
Youth League is also the fundamental purpose of higher education. Growth service is helping and guiding students to solve outstanding difficulties and problems encountered in the development of growth, to promote their healthy growth and overall development, which not only embodies the mission of the organization of care, is the Communist Youth League and students an important prerequisite. The mutual connection, the organic unity, and the service of the university students' employment and entrepreneurship work, including the young people's view of employment and entrepreneurship. Thought leading to the young Marx, the leader of the project, the growth of services to promote the employment of college students as a leader. And education work of the Communist Youth League of college students employment and entrepreneurship is not only the fundamental one of the supporting points, embodiment is the work of the Communist Youth League service center of the Party committee in Colleges and universities is an important starting point and fundamental goal of Communist Youth League in Colleges and universities and educational way.

\section{The special advantages of the university Communist Youth League helps the undergraduates get employed and entrepreneurship}

\section{A. Organizational superiority}

The Communist Youth League has complete organization system, tight structure and wide coverage. More than $95 \%$ undergraduates are League member and this complete organization system can involve students well and lead them and attract them to stay around the League organization. The student union and association are lead by the Communist Youth League directly which can know the change of student's mind best, close to their realistic request best and association students more widely and closely. The Communist Youth League has a strong cohesion and centripetal which makes the undergraduates trust and support to. The Communist Youth League has a league cadre team with high quality, dedication, closing to student and full of fighting, which can do the student's ideological work best. And the Youth League has its own features and advantages in condensing the youth, guiding the youth and serving the youth, and also is the guarantee of the university Communist Youth League serving the students.

\section{B. Carrier superiority}

The university Communist Youth League's carrier is abundant with such Youth people's bases as academic, culture and art, practical training and voluntary activity; such main battlefield as ideological and political education and situation and policy education; such plan as developing qualities of college students and serving the West voluntarily; such competition as Extracurricular contest, the Challenge-cup contest and undergraduates career planning competition; and some rich and colorful activities, such as intern plan and school cultural and science festival. These carriers have a great influence among undergraduates because it edifies the student's mind and concept gradually and imperceptibly, and help student's improve their comprehensive quality.

\section{Resource superiority}

The university Communist Youth League possesses a unique resource advantages. The abundant social and manpower resource make the Youth League's operating mechanism more apparently. Communist Youth League organization presents an open type form, covering every walks of society. Those resources superiority is an important guarantee to develop the educational work of subordination class, help the undergraduates set up correct view on profession choosing and employment and view on life.

\section{The contents and ways of the University Communist Youth League service for college students' employment and entrepreneurship.}

A. strengthen college students' employment and entrepreneurship education.

Play the traditional advantages of the Communist Youth League in college students' ideological education, strengthen the ideological guidance. College students to achieve the best match between people and occupation, need to take the lead as the core, education and guide students to establish a correct concept of employment and entrepreneurship. Employment and entrepreneurship is correct or not, whether the smooth employment and employment can actively work and give full play to the ability to play an important role. The correct concept of employment, can according to individual conditions, voluntary and social needs of the realistic choice of career, the correct treatment of the social division of labor, comfortable in the center and do their best to realize their ambitions, dedicated to the motherland. The employment outlook is not correct, will be in the job hunting choosers, blind pursuit of "hot" occupation, blindly crowded in big city. Once the desire is not met, it will be in a mood of melancholy, feeling gloomy, pessimistic disappointment. Of course, the pursuit of a good working environment and treatment is understandable, but if too choosy, fickle, will inevitably lead to high not low in the embarrassing situation. The Communist Youth League through League, league, lectures, seminars, forums, entrepreneurial alumni forum and other rich and colorful activities and network, radio, billboards and other media publicity, education and guide students to understand the situation, change the idea, set up the service base, serving the people, to the countryside, to the country where most needed to build up establishment, in the west the idea of establishing; adventure. has, "dry line, love line, do a good job" professional concept; to help students expand employment horizons, inspire entrepreneurial awareness, stimulate entrepreneurial spirit; help students clearly recognize: Wonderfull Life from the struggle, personal ideals to obey the national and social needs; the correct employment mentality, do not complain, range, do not rely on, dare to think, dare to do, dare to play, the employment with the revitalization of the Chinese nation, the prosperity of the motherland together, change from passive to active employment and entrepreneurship, change to adapt to the market to open market; rely on hard work, rely on the life and 
career of work hard and perseveringly, opened up the road ahead, create life brilliant performance.

B. Strengthen college students' employment policy, employment situation, publicity and guidance.

The employment policy is an important basis for all college students employment. Students only have a comprehensive and accurate grasp of employment policies, in order to adapt to the situation, accurate positioning, objective understanding of self, self evaluation, better safeguard their own responsibilities, rights and interests. To allow students to truly understand the policy and regulations on the employment and Entrepreneurship of university students; understand the employment system and employment channels; effective use of state preferential policies, the effective use of government, schools, community to provide entrepreneurial practice platform, in the range allowed by the employment policy of choice of occupation and work units, the smooth realization of employment and entrepreneurship.

\section{Enhance the ability of College Students' employment and Entrepreneurship.}

To improve the employment and Entrepreneurship of college students is one of the basic ways to solve the problem of employment and entrepreneurship. Extensive theoretical knowledge and deep knowledge is the basis of employment and entrepreneurship, finance, business, taxation, law, economy, trade and other knowledge is the necessary employment of the business. To actively carry out to the expansion of knowledge, the development of students "quality for the purpose of all kinds of activities, in activities not only pays attention to the complementary advantages between the students different disciplines, but also pay attention to the cultivation of students' professional knowledge, ability and quality; pay attention to the students practical ability, decisionmaking ability, strain ability, innovation ability, to avoid the risk ability, organization and management capacity to improve. We should vigorously carry out social practice, in practice to understand the social, social cognition, edify sentiment, improve the quality; to use the League advantage, invited alumni forum, imparting employment experience, provide employment opportunities; to give full play to all walks of life experts in the entrepreneurial process, consulting, coaching staff, has a supporting role, to carry out targeted training and communication; to vigorously promote the "unremitting selfimprovement, firm and indomitable, pragmatic and strong" entrepreneurial spirit, talent market oriented, the college student occupation career planning for the entry point, to help students choose life science development direction and the direction of occupation; to foster students scientific consciousness, enterprising consciousness, forming the courage to challenge, dare to question the quality of employment, be strict in one's demands; according to the students' physical and mental characteristics and aptitude, and guide them to self-improvement and shaping, improve the comprehensive quality of College students.

\section{Expand the way of College Students' Employment.}

Play the characteristics of innovation. Combination of expand contents and forms of social practice, insist on the combination of social practice and patriotism education, teaching and scientific research, students'; adhere to the social practice of centralization and decentralization, long-term and short-term combination; adhere to the community activities, volunteer service activities with local economic construction. Founded University Science and Technology Park .Relying on the University, the University's intelligence, technology and test equipment resources and employment for college students provide incubator; to have a scientific and technological achievements of college students provides the transformation of scientific and technological achievements for the product space, the environment, the hotbed; have the conditions to start a business project provides marketing, policy consulting, legal aid and financing support and other services. Improve the construction of College Students' employment and entrepreneurship training base. College Students' diversified industry base construction, by the well-known enterprises full participation in the base mutual benefit project, entrepreneurship and employment as a whole, entrepreneurship to employment, to promote employment and entrepreneurial base construction; industrial base of college students can brings together government public welfare, business management and entrepreneurship, self financing by combining the Industrial Park, to achieve sustainable development of rolling; on entrepreneurial intention and the basis of students used to track the training mode, the entrepreneurial projects do long-term planning, provide full attention and guidance, enhance the power of entrepreneurial activity; of trainee students good communication, caring for their work, concerns the life, to solve the difficulties.

\section{E. Creating employment informaiton website for college undergraduates}

If the undergraduates can get information at right time, then they can get initiative opportunity to start a business. Due to the lack of sharing information between each college, undergraduates are facing a serious problem, like information disordered between undergraduates and social workers, false information, and basic information of undergraduates are unreliable. We are trying to build an information shared mechanism which connecting undergraduates and mass organizations. Also we are trying to participate and responsible for checking how reliable about recruiting companies and undergraduate sâ€ ${ }^{\mathrm{TM}}$ information. For the purpose of building a consolidated and high-efficient undergraduate resources market, we attempted to establish a business incubation center for undergraduate.

\section{$F$. The cultivation of good psychological quality of College Students}

Along with the gradual deepening of the reform of employment system of college students, more relaxed environment for employment for their provides good opportunities for development, but severe forms of employment and that they face enormous pressure and 
challenges. At present, students of the social and economic environment, ideological and cultural environment is increasingly complicated, employment, life, physical and mental health problems are complicated, at any time may encounter contradictions, difficulties, frustration, anxiety. In this situation, it is very important to cultivate college students' psychological quality. How to face the career setbacks, how to face the venture to crossed the project ridge, ridge of funds, management ridge, that sort of thing, so early into the community college students so desperately, sleepless nights. Some students narrow field of vision, unrealistic expectations and utilitarianism and idealism thought, effect of employment and entrepreneurship smoothly, need to grasp the ideological dynamic, timely and effectively to be psychological counseling, help them comprehensively and objectively evaluate themselves, recognize their own strengths and weaknesses, overcome the blindly pessimistic attitude, courage to face the challenges and difficulties in the competition, build confidence and risk awareness, enhance their psychological endurance capacity.

\section{University Communist Youth League service students employment and entrepreneurship should be based on the students.}

The Communist Youth League in the service of university students' employment guidance and education work, to respect the dominant position of students, establish the studentcentered idea; to keep in mind the "respect and understand students, care for students" is the work of the Communist Youth League policy; "represent the interests of students, reflect the students' desire" is the work of the Communist Youth League to ideological themes; as the core of political education, education and guidance; to rely on personnel caring, sincere service, give full play to group cohesion, charisma; be matched with the school, the society and the relevant departments to coordinate, to promote college students' employment and entrepreneurship; according to the characteristics and needs of students of different stages, from the aspects of culture, consciousness the quality of development, improve the skills, practice and so on; to Scientific Outlook on Development as guidance, constantly innovate the work mechanism and means of work, emancipate the mind, scientific guidance, enhance service awareness, improve service skills.

\section{Conclusion}

It's the fundamental policy of our party and country that promote our college students' employment. To provide service to students' employment and entrepreneurship is an important function of the Communist Youth League in Colleges and Universities. In order to play the function role of the Communist Youth League, and contribute to the service of the party's central work, we should have a actively explorement from the play of the advantages of the Communist Youth League, the role of the employment of college students, the content, methods, content and methods.

\section{References}

[1] Shi Xianfeng. New thinking (ideas) on Communist Youth Leagues' service for the employment and enterpreneurship of college students. Education and Vocation, 2012 (6): 165--166.

[2] Gao Hongxing. Supporting college students' enterpreneurship by giving play of Communist Youth League' ability to organize. Journal of Zhejiang Youth College, 2010 (3).

[3] Zhang Yu. Educate and guide students to establish the scientific concept of employment and entrepreneurship concept. Journal of Guangxi College of Education, 2009 (3): 30--31.

[4] He Tingying. A survey and study on the career consciousness of college students. China Youth Study, 2007 (1): 45--48. 